Dept. of Res. and Diag. of Poultry Diseases,

Animal Health Research Institute, Dokki, Giza, Egypt

\title{
ANTIGENIC VARIATIONS BETWEEN DIFFERENT SALMONELLA SEROTYPES ISOLATED FROM CHICKENS
}

(With 6 Tables and 2 Photos)

By

\author{
JIHAN M. BADR and HODA ABD EL MONEM* \\ *Dept. of Biotechnology, Animal Health Research Institute, \\ Dokki, Giza, Egypt \\ (Received at 13/2/2008)
}

الاختلافات الأنتيجينية بين عترات السالمونيلا المختلفة المعزولة من الاجاج

\section{جيهان مصطفى بلر ، هلى عبد المنعم}

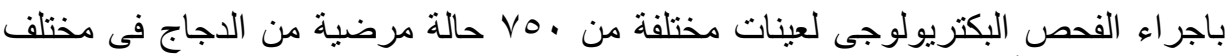

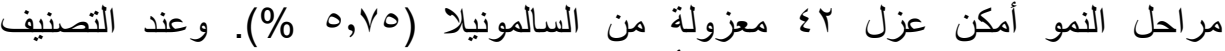

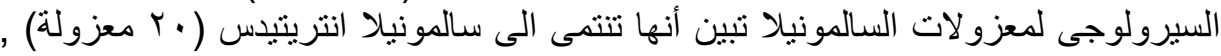

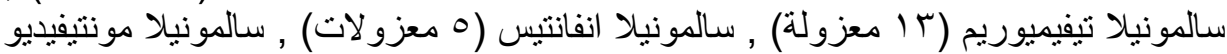

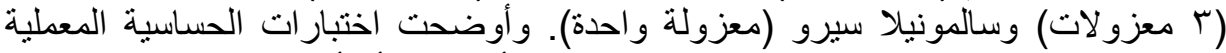

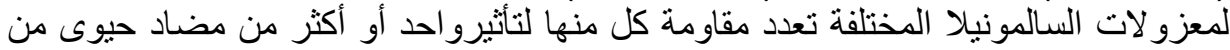

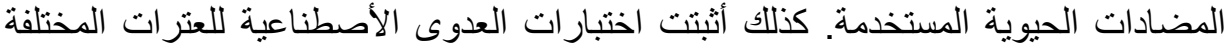

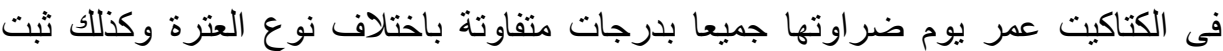

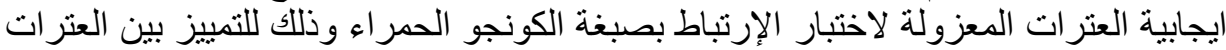

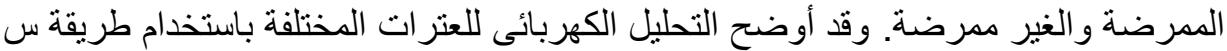

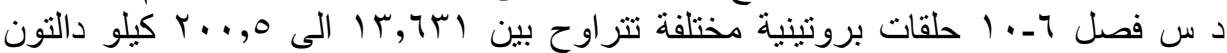

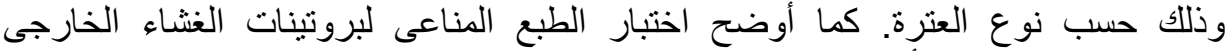

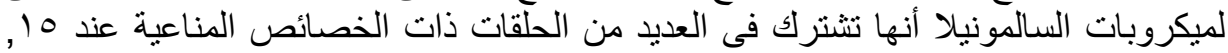

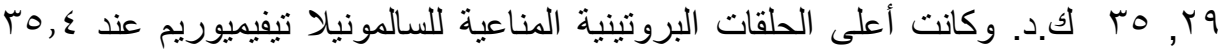

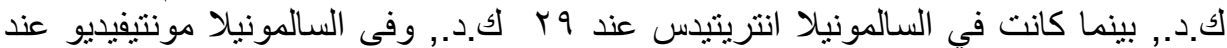

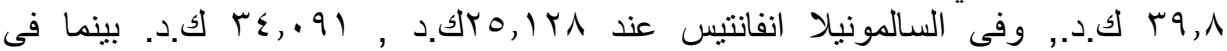

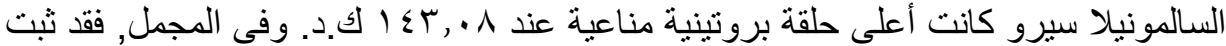

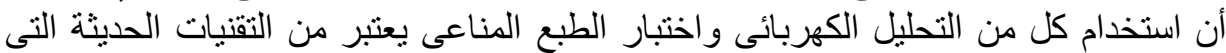

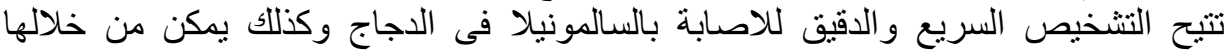

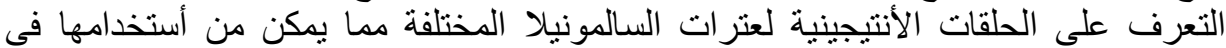
أنتاج لقاح للوقاية من الاصابة بالسالمونيلا فى الأباج. 
Examination of different samples from 750 chicken cases of various growth stages, revealed the isolation of 42 Salmonella isolates (5.75\%). The isolated salmonellae were serotyped as Salmonella enteritidis (20 isolates), Salmonella typhimurium (13 isolates), Salmonella infantis (5 isolates), Salmonella montivideo (3 isolates) and Salmonella cerro (1 isolate). Antibiogram of the isolated Salmonellae indicated multidrugresistance to one or more than of the tested antimicrobial agents. Pathogenicity tests in one-day old chicks proved the virulence of all examined serovars with various degrees of pathogenicity and all were positive for congo red activity. SDS-PAGE protein analysis of different serovars revealed 6-10 protein bands ranged from 13.631-200.5 KD, which in relation to the isolated Salmonella serovar. Immunoblotting of the isolated serovars revealed the presence of common protein bands at 15,29 and $35 \mathrm{KD}$. The highest antigenicity protein band of $S$. typhimurium was detected at $35.4 \mathrm{KD}$, while in $S$. enteritidis was detected at 29KD; in S. montivideo at $39.8 \mathrm{KD}$; in S. infantis at 25.128 and $34.091 \mathrm{KD}$, while $S$. cerro had the highest antigenic protein band at 143.08KD. In conclusion, SDS-PAGE analysis and immunoblot provide a recent and accurate techniques for detection of salmonellosis in chickens, in addition to offer the use of immunogenicity of different detected immunogenic bands to serve as components of an effective subcellular vaccine for poultry salmonellosis.

Key words: Chickens, Salmonella, antimicrobial agents

\section{INTRODUCTION}

In the last decades, poultry and poultry products have been the main source of non-host specific Salmonella infecting humans (Shahata, 1979, Abd El-Hamid et al., 2004 and Murugkar et al., 2005). Poultry are commonly infected with a wide variety of Salmonella serovars and there has been considerable variation in the occurrence of the most common Salmonella serovars in domestic fowls in different countries and at different times. The outer membrane protein analysis has proved to be useful technique in characterization of Salmonella (Fadl et al., 2002 and Ochoa-Reparz et al., 2004). On the practical basis, detection of flock infections remains one of the most serious unsolved problems in controlling salmonellosis in poultry. Serological studies of different salmonellae revealed the presence of cross reaction between Salmonella 
organisms and other members of family Enterobacteriaceae such as Escherichia coli and Proteus spp., due to the presence of a common antigen (Le-Minor et al., 1982). Thus, increased interest for the control of salmonella in poultry requires the development of improved detection methods. Western immunoblotting is a convenient, sensitive specific technique for the detection of antigen and antibodies (Kim and Nagaraja, 1991). The purpose of this research work was to determine the incidence of different Salmonella serovars isolated from chickens at different stages of growth with reference to their protein analysis using SDSPAGE as well as to study the virulence pattern of different serovars in relation to the antigenic variation between them using immunoblotting technique.

\section{MATERIALS and METHODS}

\section{Chicken specimens:}

Samples from liver, spleen, intestines (ceci and cecal tonsils), yolk sacs and bone marrows were collected under complete aseptic conditions from 750 chicken cases at different growth stages (chicks, broilers and parents) either dead (180 cases) or living ailing (550 cases) in the period from January 2006 up to March 2007. The samples were submitted to Bacteriological Unit of the Department of Diagnosis and Research of Poultry Diseases, Animal Health Research Institute, Dokki, Giza, Egypt, to be examined bacteriologically for the isolation of different salmonellae.

\section{Isolation and identification of Salmonella from chickens}

Isolation of different salmonellae from chicken samples was carried out according to Mallinson and Snoeyenbos (1994). Suspected colonies were identified morphologically, culturally and biochemically according to Holt et al., 1996 and Collier et al., 1998). Serological identification was carried out by slide agglutination test using polyvalent and monovalent $[\mathrm{O}]$ and $[\mathrm{H}]$ Salmonella antisera according to Kauffmann-White scheme described by Kauffmann (1974).

Antibiogram of the isolated salmonellae: In-vitro susceptibility testing of Salmonella isolates to various antimicrobial agents was determined using NCCLS method (NCCLS, 2003). Ten different commercial antibiotic discs (Oxoid) were used.

Pathogenicity tests of the isolated Salmonella serovars:

\section{1-Pathogenicity in one-day old chicks:}

Six groups (1 to 6) each of twenty, one-day old chicks which proved to be salmonella-free, were used for pathogenicity testing of various isolated Salmonella serovars. Each group was divided into two 
sub-groups A and B. Chicks in sub-groups A were infected orally with $3 \times 10^{8}$ CFU (colony forming units) of one of the isolated serovars namely: Salmonella enteritidis, Salmonella typhimurium, Salmonella infantis, Salmonella montivideo and Salmonella cerro. Chicks in subgroups B were inoculated intrapretoneally with one of the same serovars at the same dose, while the $6^{\text {th }}$ subgroups were given $0.5 \mathrm{ml}$ of sterile saline solution orally and intrapretoneally, respectively and were saved as non infected control. All chicks in different groups were kept separately and monitored for clinical signs and mortality for 14 days post-infection (Bakshi et al., 2003). Postmortem examinations accompanied by re-isolation of the infected microorganisms from internal organs of dead chicks in different groups were attempted.

2- Congo red (CR) test: All Salmonella isolates were tested for its growth status on congo red medium modified according to Berkhoff and Vinal (1986).

SDS-PAGE technique: Salmonella antigens were prepared after Ahmed et al., (1998). Protein of various Salmonella serovars was separated by SDS-PAGE using the discontinuous buffer system described by Laemmli (1970).

\section{Western blotting:}

A- Preparation of Salmonella antisera: New Zealand white rabbits were used to produce antisera against different isolated salmonella serovars according to Kim and Nagaraja (1991).

B- Application of Western immunoblotting: To identify proteins specific for each of the isolated Salmonella serovars, Western blotting was done using the prepared salmonella antisera according to the procedure described by Talbot et al., (1984) The outer membrane proteins (OMPs) of different salmonella serovars were separated by SDS-PAGE by the method described by Laemmli (1970) and were electrophoretically transferred to a nitrocellulose filter using transphor electrophoresis unit cell with electroblotting buffer containing $25 \mathrm{mM}$ Tris, $192 \mathrm{mM}$ glycine, and 20\% methanol, $\mathrm{pH} \mathrm{8.3.} \mathrm{The} \mathrm{nitrocellulose}$ filter strips were stained by Ponceau S red staining (Sigma), to check the transferred proteins and destained in distilled water. The strips were then immersed in Tris-buffered saline (TBS) containing $20 \mathrm{mM}$ Tris, 500 $\mathrm{mM} \mathrm{NaCl}$, and $3 \%$ gelatin, $\mathrm{pH} 7.5$, for 1 hour at $37^{\circ} \mathrm{C}$. The nitrocellulose filters were rinsed briefly in Tris-Tween buffer saline (TTBS) containing $0.05 \%$ Tween-20 in TBS buffer, $\mathrm{pH}$ 7.5. The resulting blots were incubated for 3 hours at $37^{\circ} \mathrm{C}$ with serum containing rabbit antiSalmonella antibodies of the corresponding Salmonella serovar diluted 
in TTBS containing $1 \%$ gelatin. The unbound antibodies were removed by rinsing the blot in TTBS and the bound antibodies were detected by using conjugate labeled with horseradish peroxidase (HRP) and substrate 4 chlor-1-naphthol (Sigma).

\section{RESULTS}

Table 1: Prevalence of Salmonella isolation from chickens.

\begin{tabular}{|c|c|c|c|}
\hline \multicolumn{2}{|c|}{ Examined cases } & \multicolumn{2}{c|}{ Salmonella positive } \\
\hline Type & Number & Number & $\%$ \\
\hline \multirow{2}{*}{ Living ailing } & 550 & 33 & 6 \\
Dead & 180 & 9 & 5 \\
\hline Total & & & 5.75 \\
\hline
\end{tabular}

Table 2: incidences, Congo red activity and antigenic structures of Salmonella serovars isolated from chickens

\begin{tabular}{|c|c|c|c|c|c|c|c|}
\hline \multirow{2}{*}{$\begin{array}{l}\text { Salmonella } \\
\text { Serovar }\end{array}$} & \multicolumn{2}{|c|}{ Total } & \multicolumn{2}{|c|}{ Congo red activity } & \multirow[t]{2}{*}{ Sero-group } & \multicolumn{2}{|c|}{ Antigenic structure } \\
\hline & No. & $\%$ & Positive & Negative & & {$[\mathrm{O}]$} & {$[\mathrm{H}]$} \\
\hline S.enteritidis & 20 & $47.62 \%$ & 20 & 0 & D1 & $1,9,12$ & $\mathrm{~g}, \mathrm{~m}$ \\
\hline S.typhimurium & 13 & $30.95 \%$ & 13 & 0 & B & $1,4,5,12$ & $\mathrm{i}: 1,2$ \\
\hline S.infantis & 5 & $11.90 \%$ & 5 & 0 & $\mathrm{C} 1$ & 6,7 & $\mathrm{r}: 1,5$ \\
\hline S.montivideo & 3 & $7.14 \%$ & 3 & 0 & $\mathrm{C} 1$ & 6,7 & $\mathrm{~g}, \mathrm{~m}, \mathrm{~s}, \mathrm{p}$ \\
\hline S.cerro & 1 & $2.38 \%$ & 1 & 0 & K & $6,14,18$ & $\mathrm{Z} 4, \mathrm{Z} 28: 1,5$ \\
\hline Total & 42 & $100 \%$ & 42 & 0 & & & \\
\hline
\end{tabular}

Table 3: Antibiogram of salmonellae isolated from chickens. 
Assiut Vet. Med. J. Vol. 54 No. 117 April 2008

\begin{tabular}{|c|c|c|c|c|}
\hline \multirow{2}{*}{$\begin{array}{c}\text { Antimicrobial } \\
\text { agents }\end{array}$} & \multirow{2}{*}{$\begin{array}{c}\text { Disc } \\
\text { conc. } \\
(\mu \mathrm{g})\end{array}$} & $\begin{array}{c}\text { Sensitive } \\
(\%)\end{array}$ & $\begin{array}{c}\text { Intermediate } \\
(\%)\end{array}$ & $\begin{array}{c}\text { Resistant } \\
(\%)\end{array}$ \\
\cline { 3 - 5 } & 25 & $9 / 42(21.4 \%)$ & $0 / 42(0 \%)$ & $33 / 42(78.6 \%)$ \\
Ampicillin & 20 & $0 / 42(0 \%)$ & $5 / 42(11.9 \%)$ & $37.42(88.1 \%)$ \\
Amoxicillin & 30 & $31 / 42(73.8 \%)$ & $11 / 42(26.2 \%)$ & $0 / 42(0 \%)$ \\
Cephridin & 30 & $15 / 42(35.7 \%)$ & $2 / 42(4.7 \%)$ & $25 / 42(59.5 \%)$ \\
Chloramphenicol & 10 & $42 / 42(100 \%)$ & $0 / 42(0 \%)$ & $0 / 42(0 \%)$ \\
Ciprofloxacin & 10 & $42 / 42(100 \%)$ & $0 / 42(0 \%)$ & $0 / 42(0 \%)$ \\
Danofloxacin & 10 & $42 / 42(100 \%)$ & $0 / 42(0 \%)$ & $0 / 42(0 \%)$ \\
Norfloxacin & 10 & $14 / 42(33.3 \%)$ & $5 / 42(11.9 \%)$ & $23 / 42(54.7 \%)$ \\
Gentamycin & 30 & $0 / 42(0 \%)$ & $3 / 42(7.1 \%)$ & $39 / 42(92.9 \%)$ \\
Tetracycline & & & & $0 / 42(0 \%)$ \\
Sulphamethoxazole- & 25 & $31 / 42(73.8 \%)$ & $11 / 42(26.2 \%)$ \\
trimethoprim & 25 & &
\end{tabular}

Table 4: Pathogenicity tests of isolated Salmonella serovars in one-day old chicks.

\begin{tabular}{|c|c|c|c|c|c|c|c|c|c|c|c|c|c|c|c|c|c|c|}
\hline \multirow{2}{*}{$\begin{array}{l}\text { GP. } \\
\text { NO. }\end{array}$} & \multirow{2}{*}{$\begin{array}{c}\text { Salmonella } \\
\text { serovar }\end{array}$} & \multirow{2}{*}{$\begin{array}{l}\text { Sub- } \\
\text { group }\end{array}$} & \multirow{2}{*}{$\begin{array}{l}\text { Route of } \\
\text { infection }\end{array}$} & \multicolumn{13}{|c|}{ Number of dead chicks /day* } & \multicolumn{2}{|c|}{ Total } \\
\hline & & & & 1 & 2 & 3 & 4 & 5 & 6 & 7 & 8 & 9 & 10 & 11 & 12 & 13 & NO. & $\%$ \\
\hline \multirow{2}{*}{1} & \multirow{2}{*}{ S.entiritidis } & A & Oral & 0 & 0 & 2 & 2 & 0 & 1 & 0 & 1 & 0 & 0 & 1 & 1 & 0 & 8 & 80 \\
\hline & & B & $\mathrm{I} / \mathrm{P}$ & 7 & 3 & 0 & 0 & 0 & 0 & 0 & 0 & 0 & 0 & 0 & 0 & 0 & 10 & 100 \\
\hline \multirow{2}{*}{2} & \multirow{2}{*}{ S. typhimurium } & A & Oral & 0 & 0 & 2 & 2 & 2 & 1 & 0 & 1 & 0 & 1 & 0 & 0 & 0 & 9 & 90 \\
\hline & & B & $\mathrm{I} / \mathrm{P}$ & 9 & 1 & 0 & 0 & 0 & 0 & 0 & 0 & 0 & 0 & 0 & 0 & 0 & 10 & 100 \\
\hline \multirow{2}{*}{3} & \multirow{2}{*}{ S. infantis } & A & Oral & 0 & 0 & 2 & 1 & 1 & 1 & 1 & 0 & 0 & 0 & 0 & 1 & 0 & 7 & 70 \\
\hline & & B & $\mathrm{I} / \mathrm{P}$ & 6 & 4 & 0 & 0 & 0 & 0 & 0 & 0 & 0 & 0 & 0 & 0 & 0 & 10 & 100 \\
\hline \multirow{2}{*}{4} & \multirow{2}{*}{ S.montivideo } & A & Oral & 0 & 0 & 0 & 1 & 2 & 2 & 0 & 1 & 1 & 1 & 0 & 0 & 0 & 8 & 80 \\
\hline & & B & $\mathrm{I} / \mathrm{P}$ & 7 & 3 & 0 & 0 & 0 & 0 & 0 & 0 & 0 & 0 & 0 & 0 & 0 & 10 & 100 \\
\hline \multirow{2}{*}{5} & \multirow{2}{*}{ S.cerro } & A & Oral & 0 & 0 & 0 & 1 & 1 & 1 & 2 & 2 & 0 & 1 & 1 & 1 & 0 & 7 & 70 \\
\hline & & B & $\mathrm{I} / \mathrm{P}$ & 8 & 2 & 0 & 0 & 0 & 0 & 0 & 0 & 0 & 0 & 0 & 0 & 0 & 10 & 100 \\
\hline \multirow{2}{*}{6} & \multirow{2}{*}{ Control negative } & A & Oral & 0 & 0 & 0 & 0 & 0 & 0 & 0 & 0 & 0 & 0 & 0 & 0 & 0 & 0 & 0 \\
\hline & & B & $\mathrm{I} / \mathrm{P}$ & 0 & 0 & 0 & 0 & 0 & 0 & 0 & 0 & 0 & 0 & 0 & 0 & 0 & 0 & 0 \\
\hline
\end{tabular}


Table 5: The molecular weights (Mol.wt.) of Salmonella serovars compared with the molecular weights of the Sigma marker

\begin{tabular}{|c|c|c|c|c|c|c|}
\hline Lanes: & Lane 1 & Lane 2 & Lane 3 & Lane 4 & Lane 5 & Lane 6 \\
\hline Bands & (mol.w.) & (mol.w.) & (mol.w.) & (mol.w.) & (mol.w.) & (mol.w.) \\
\hline 1 & 250 & 180.88 & 200 & 200 & 200.5 & 200.33 \\
\hline 2 & 160 & & 150.5 & 180.3 & 150.9 & 150 \\
\hline 3 & 130 & 120.3 & & & & \\
\hline 4 & 105 & & 100.66 & & 100 & 100.25 \\
\hline 5 & 85 & & & & & \\
\hline 6 & 75 & & 75.1 & 75.00 & & 75.4 \\
\hline 7 & 66 & 60.15 & 62.5 & 62.112 & & 62.71 \\
\hline 8 & 50 & & &. & & 36.532 \\
\hline 9 & 35 & 35.00 & 35.00 & 34.00 & 35.00 & 25.921 \\
\hline 10 & 24 & 26.00 & 25.721 & 25.66 & 25.00 & \\
\hline 11 & & & & & & \\
\hline 12 & 18.4 & & 19.095 & 18.559 & & 15.631 \\
\hline 13 &. & 15.471 & 15.81 & 15.643 & 15.532 & \\
\hline 14 & 14.3 & & 14.5 & & & 13.5 \\
\hline
\end{tabular}

Lane (1): protein marker Lane (2): S.cerro Lane (3): S.enteritidis Lane(4): S.infantis Lane (5): S.montivideo Lane (6): S.typhimurium

Table 6: The amount of protein and molecular weight of bands of western blot of Salmonella species compared with the molecular weights of western blot of bio lab-broad range prestained molecular weights marker

\begin{tabular}{|c|c|c|c|c|c|c|c|c|c|c|c|c|}
\hline \multirow{2}{*}{$\begin{array}{l}\text { Lanes: } \\
\text { Bands }\end{array}$} & \multicolumn{2}{|c|}{$\begin{array}{c}\text { Lane } 1 \\
\text { S.t yphimurium }\end{array}$} & \multicolumn{2}{|c|}{$\begin{array}{l}\text { Lane } 2 \\
\text { S.cerro }\end{array}$} & \multicolumn{2}{|c|}{$\begin{array}{c}\text { Lane } 3 \\
\text { S.enteritidis }\end{array}$} & \multicolumn{2}{|c|}{$\begin{array}{c}\text { Lane } 4 \\
\text { S.montivideo }\end{array}$} & \multicolumn{2}{|c|}{$\begin{array}{c}\text { Lane } 5 \\
\text { S.infantis }\end{array}$} & \multicolumn{2}{|c|}{$\begin{array}{l}\text { Lane } 6 \\
\text { marker }\end{array}$} \\
\hline & (mol.w.) & (amount) & (mol.w.) & (amount) & (mol.w.) & (amount) & (mol.w.) & (amount) & (mol.w.) & (amount) & (mol.w.) & (amount) \\
\hline 1 & 147.31 & 6.1287 & 143.08 & 12.483 & 103.13 & 8.7253 & 138.85 & 22.82 & 97.5 & 2.7242 & 250 & 9.1327 \\
\hline 2 & 70.968 & 8.1718 & 59.677 & 6.7738 & & & & & & & 160 & 19.524 \\
\hline 3 & 43.8 & 3.0548 & 43 & 9.7839 & & & & & & & 105 & 21.988 \\
\hline 4 & 42.2 & 6.7024 & & & 41.4 & 3.619 & 41.8 & 3.8294 & 40.2 & 34.197 & 75 & 9.1018 \\
\hline 5 & 39 & 2.0458 & 39.2 & 2.4591 & 39.6 & 6.2596 & 39.8 & 12.591 & 34.945 & 2.5488 & 50 & 12.279 \\
\hline 6 & 35.4 & 34.717 & 35.788 & 7.04 & 34.924 & 1.6107 & 35.194 & 2.7216 & 34.091 & 38.626 & & \\
\hline 7 & 33.41 & 3.337 & 33.273 & 4.3285 & 33.409 & 5.4027 & 33.12 & 1.9114 & 33.333 & 3.3596 & 35 & 9.5337 \\
\hline 8 & 29.12 & 13.222 & 29.3 & 5.5432 & 29 & 11.651 & 29.421 & 11.038 & 29.11 & 12.097 & 30 & 7.4348 \\
\hline 9 & 27.179 & 4.5188 & 27.051 & 3.1935 & 27 & 2.7661 & 27 & 0.47963 & 25.128 & 68.032 & 25 & 21.37 \\
\hline 10 & 23.793 & 5.8539 & 23.276 & 6.5721 & 23.032 & 8.5662 & 23.1 & 3.9863 & 23.119 & 7.521 & & \\
\hline 11 & 19.31 & 24.97 & 18.276 & 7.744 & 17.759 & 6.0615 & 18.103 & 4.1006 & & & & \\
\hline 12 & 16.552 & 29.288 & 16.034 & 8.1082 & & & & & & & & \\
\hline 13 & 15 & 31.448 & 15 & 4.2871 & 15 & 9.3732 & 15 & 6.8058 & 15.345 & 12.578 & 15 & 9.0185 \\
\hline 14 & & & & & 11.875 & 6.9632 & 11.875 & 12.288 & 13.125 & 17.064 & 10 & 10.736 \\
\hline
\end{tabular}


Photo 1: SDS-PAGE protein profile of Salmonella serovars isolated from chickens.

Lane (1): protein marker, Lane (2): S. cerro, Lane (3): S. enteritidis, Lane (4): S. infantis, Lane (5): S. montevideo, Lane (6): S. typhimurium

Photo 2: Western immunoblot of Salmonella serovars isolated from chickens.

Lane (1): S.typhimurium, Lane (2): S.cerro, Lane (3): S.enteritidis, Lane(4):S.montevideo, Lane (5): S.infantis, Lane(6): protein marker 


\section{DISCUSSION}

Bacteriological examination of different samples obtained from chicken cases at different ages revealed that out of 730 examined cases 42 Salmonella isolates were obtained with an incidence of $5.75 \%$ (Table $1)$.

Similar results were obtained by Hassan et al., 2003 who isolated 35 Salmonella isolates (5.51\%) out of 635 examined chicken samples. On serotyping of the isolated Salmonellae (Table 2) revealed that Salmonella enteritidis was the most predominant isolated serovar (47.62\%) followed by Salmonella typhimurium (30.95\%). These results agreed with that obtained by Abd-Allah et al., (1995), who surveyed a large number of samples from different domestic birds and their environmental surroundings in El-Fayoum governorate and found that Salmonella enteritidis was the most prevalent isolated serovar (40\%) followed by Salmonella typhimurium (24\%), Salmonella montivideo (16\%). However, it was noticed that during the last 10-15 years, Salmonella enteritidis has replaced Salmonella typhimurium as the commonest serovar in many countries worldwide (Poppe, 2000). Isolates of Salmonella infantis constituted $11.9 \%$ of the total number of Salmonella isolates which agreed with the results obtained by Novak and Polaharova (1993) and Hassan et al., (2003). Salmonella montivideo represented $7.14 \%$ of the isolated salmonellae, while Salmonella cerro constituted $2.38 \%$. the same serovars were isolated from poultry samples with different incidences by many authors (Barnhart et al., 1992, AbdAllah 1995 and Hofer et al., 1998).

Concerning Congo red binding activity, all the isolated Salmonellae were proved to be Congo red positive. It was reported that Congo red binding activity was correlated to the invasiveness of bacteria, as fimbria promote the binding of the hydrophobic dye Congo red by the bacteria that produce such fimbria (Qadri et al., 1988). Thus, Congo red binding test may provides a simple and rapid test for screening Salmonella strains which harbor fimbria (Dorn et al., 1992).

Antibiogram of the isolated Salmonellae (Table 3) revealed multi-resistant to more than one of the tested antibiotics. However the isolates were sensitive to Ciprofloxacin, Danofloxacin and Norfloxacin (100\%) followed by Cephridine and Sulfamethxazole-trimethoprim (73.8\% for each).

Similar results were obtained by Lee et al., (2003) and Gorman and Adley (2004). Also, resistance to Tetracycline, Amoxycillin and 
Ampicillin (92.9\%, 88.1\% and 78.6\%, respectively) were detected which agreed with Botteldoorn et al., (2004) and Johnson et al., (2005). It was reported that multi-drug resistant Salmonella serovars cause severe and septicemic salmonellosis more frequently than those which are nonresistant (Helms et al., 2002 and Gupta et al., 2003).

The high incidence of antibiotic resistance among the tested salmonellae may be due to the misuse of antibiotics in addition to underdosing and using the antibiotics as feed additives.

The pathoginicity testing of the isolated serovars in one-day old chicks (Table 4) revealed a variation in the degree of virulence in correlation to the variation of the type of serovar and route of infection. The mortality rates ranged from $70 \%-100 \%$ in case of oral infection, while reached $100 \%$ mortalities in all groups of chicks infected intraperitoneally. However, many factors can influence the relative pathogenicity of Salmonella in chicks, which includes the age of the chickens at the time of infection, route of infection, presence of competing bacteria in the intestinal tract and the dose of infection (Cox et al., 1990; Cooper et al., 1994 and Bailey et al., 2001).

Mortalities appear within 24 hours after intraperitoneal infection and within 48-72 hours after oral infection. The main clinical symptoms were pyrexia, diarrheoa and inability to stand while the postmortem lesions revealed congestion of all internal organs specially in intraperitoneal infection associated with the isolation of the inoculated serovar. These results agreed with Bailey et al., (2005) who recovered Salmonella from liver, thymus, spleen, bursa and ceca within 24 hours after oral inoculation.

The outer membrane proteins (OMPs) of salmonella and its compositions have been a subject of growing interest during the last few decades (Roushdy, 1998). In this work, (OMPs) of the isolated Salmonella serovars have been analyzed and electrophoresis' profiles have been determined by sodium dodocyle sulphate polyacrylamide gel electrophoresis (SDS-PAGE) and resolved into protein bands as shown in Photo (1) and Table (5)

SDS-PAGE results revealed the determination of 6-10 protein bands ranging from 13.631 -200.5 kilo Dalton (KD). Nearly similar results were obtained by El-Reedy et al. (2007) who identified about 12 different protein bands ranging from 22-289 KD by SDS-PAGE analysis of 12 different salmonella serotypes isolated from poultry. Also there were common protein bands at 15, 26 and $35 \mathrm{KD}$ identified in all isolated Salmonella serovars which agreed with the results obtained by 
Ames (1973), Sarasombath et al. (1988) and Joradat and Zawistowski (1998) who detected the presence of $35 \mathrm{KD}$ protein band in all examined salmonellae. On the other hand, $S$. cerro was characterized by 3 deeply stained protein bands at 120, 60.15 and $26 \mathrm{KD}$.; S. enteritidis was characterized by 4 deeply stained protein bands at 150.5, 100.66, 75.1 and $620.5 \mathrm{KD} ; S$. infantis has 3 deeply stained protein bands at 180.2, 75 and $62.112 \mathrm{KD} ; S$. montivideo characterized by 2 deeply stained protein bands at $150.9 \mathrm{KD}$ and $100 \mathrm{KD}$, while $S$. typhimurium obtained 5 deeply stained protein bands at $150,100.25,75.4,62.71$ and $36.532 \mathrm{KD}$. It is clear that the protein composition in relation to Salmonella serovars which agreed with the results obtained by Roushdy (1998).

SDS-PAGE immuonoblot procedure provided a rapid method for providing serological evidence of infection with Salmonella (Chart et al., 1997). In this study, SDS-PAGE immuonoblotting detected 10-13 antigenic protein bands ranged from 11.8-147.3 KD as shown in Photo (2) and Table (6) with the detection of more protein bands which could not be detected in gel electrophoresis. This may be due to that immunoblot is more specific technique than gel electrophoresis so any epitopes can be captured by antibodies. It was noticed that the highest antigenicity protein band of $S$. typhimurium was detected at $35.4 \mathrm{KD}$, while in S. enteritidis was detected at $29 \mathrm{KD}$; in $S$. montivideo at 39.8 KD; in S. infantis at 25.128 and $34.091 \mathrm{KD}$ while $S$. cerro had the highest antigenic protein band at 143.08. Similar results obtained by Nese et al. (2003) who found that Salmonella typhimurium isolates contain OMPs have the highest antigenicity common fractions at 36-43 KD. Moreover, SDS-IMMUNOBLOT of the five Salmonella serovars showed the presence of common protein bands at 15, 29 and $35 \mathrm{KD}$ which may constitute the common genus antigen. These results agreed with that obtained by Nasef (1995) who studied the immunogenicity of Salmonella common protein detected at $29 \mathrm{KD}$ and revealed the immunologic specificity of this band against antisera of different studied salmonella serotypes. Also Fathi (2004) recognized the 35 KD protein band in all examined salmonellae.

On the other hand, it was noticed the presence of shared immunogenic protein bands between different Salmonella serovars which may be the reason of cross reaction between Salmonella serovars. Similar results were obtained by Timoney et al. (1990) and Van Zijderveld et al. (1992) who observed the presence of cross reaction between different Salmonella serotypes specially group B and D1 in ELISA based on whole flagella antigen. Also, Cooper and Thorn (1996) 
reported that rabbit sera raised against Salmonella montivideo reacted strongly with Salmonella enteritidis flagellins. The cross reactions may be attributed to common epitopes present on different flagellins.

In conclusion, this study has been able to identify the differences in the organization of the proteins of the isolated Salmonella serovars which demonstrated the potential use of SDS-PAGE analysis and immuonoblotting as a recent and accurate techniques for detection of salmonellosis in chickens and the use of immunogenicity of different detected immunogenic bands to serve as components of an effective subcellular vaccine for poultry salmonellosis.

\section{REFERENCES}

Abd-Allah, M. (1995): Microbiological studies of naturally and experimentally occurring Salmonella organisms in poultry and their environments in El- Fayoum governorate. PH.D thesis, (Bacteriology) Fac. Vet. Med., Cairo Univ., (Beni-Suef branch).

Abd-El Hamid, H.S.; Torkey, H.A.; AL Shaboury, F.A.; Meran, M.A. ; Sleim Ellakany and Awad, A.M. (2004): Epidemiological studies on salmonellosis in poultry. The 4th Scientific conference, 2-4 October 2004, Fac. Vet. Med., Alexandria University.

Ahmed, M.; Hameed, A. and Sultana, K. (1998): Antimicrobial susceptibility and whole cell protein analysis of Salmonella isolates from poultry. Pakistan J. Zool., 30(4): 365-369.

Ames, G.F. (1973): Antigenically stable $35 \mathrm{KD}$ outer membrane protein of Salmonella. Food and Agricultural Immuonology, 10 (3): 259-270.

Bailey, J.S.; Stern, N.J.; Fedorka-Cray, P.; Craven, S.E.; Cox, N.A.; Cosby, D.E.; Ladely, S. and Musgrove, M.T. (2001): Sources and movement of Salmonella through integrated poultry operations: A multistate epidemiological investigation. J. Food Prot. 64: 1690-1697.

Bailey, J. S.; Cox, N.A.; Cosby, D.E. and Richardson, L.J. (2005): movement and persistence of Salmonella in broiler chickens followed oral and intracloacal inoculation. J. Food Prot., 68(12): 2698-2701.

Bakshi, C.S.; Singh, V.P.; Malik, M.; Singh, R.K and Sharma, B. (2003): 55kb plasmid and virulence - Associated genes are positively correlated with Salmonella enteritidis pathogenicity in mice and chickens. Vet., Res. Common. 27: 425 - 432.

Barnhart, H.M.; Dreesen, D.W.; Bostien, R. and Pancorbo, A.C. (1992): Prevalence of J. Food Prot and other serovars on ovary of layer hens at slaughter time. J. Food Prot., 54 (7): 488-491. 
Berkhoff, H.A. and Vinal, A.C. (1986): Congo red medium to distinguish between invasive and non-invasive Echerichia coli pathogenic for poultry. Avian Dis., 30(1): 117-121.

Botteldoorn, N.; Herman, L.; Rijpens, N. and Heyndrick, M. (2004): Phenotypic and molecular typing of Salmonella strains revealed different contamination sources in two commercial pig slaughter houses. Appl, Environ. Microbiol., 70 (9): 5305- 5314.

Chart, H.; Rowe, B. and Cheesbrough, J.S. (1997): Serological response of patients infected with Salmonella typhi. J. Clin. Pathol., Nov. 50 (11): 944-946.

Collier, L.; Balows, A. and Sussman, M. (1998): Microbiology and microbial infection. Topley and Wilson's 9th Ed.

Cooper, G.L. and Thorns, C.J. (1996): Evaluation of SEF14 fimbrial dot blot and flagellar western blot tests as indicators of Salmonella enteritidis infection in chickens. Vet. Rec., 138:149-153.

Cooper, G.L.; Venables, L.M.; Woodward, M.J. and Hormaeche, C.E. (1994): Invasiveness and persistence of Salmonella enteritidis, Salmonella typhimurium and genetically defined Salmonella enteritidis aroA strain in young chickens. Infect. Immun., 62 (11): 4739- 4746.

Cox, N.A.; Bailey, J.S.; Blankenship, L.C.; Meinermann, R.J.; Stern, N.J. and McHan, F. (1990): fifty percent colonization dose for Salmonella typhimurium administered orally and intracloacally to young broiler chicks. Poultry Sci., 69: 1809-1812.

Dorn, C.R.; Silapanuntakul, R.; Angrick, E.J. and Shipman, L.D. (1992): Plasmid analysis and epidemiology of Salmonella enteritidis infection in three commercial layer flocks. Avian Dis., 36: 844-851.

El-Reedy, S.A.; Hussein, K. Eldeen and Jihan M. Badr (2007): Protein analysis for comparison of Salmonellae isolated from different species of poultry. Beni- Suef Vet. Med. J., july, 17 (2): 1-9.

Fadl, A.A.; Venkilanarayanan, K.S. and Khan, M.I. (2002): Identification of Salmonella enteritidis outer membrane proteins expressed during attachment to human intestinal epithelial cells. J. Appl. Microbiol., 29(1):180-186.

Fathi, A.A. (2004): Protective immunity induced by outer membrane proteins and lipopolysaccharides against Salmonella infection. $6^{\text {th }}$ scientific conference of the Egyptian Veterinary poultry Association, Sept., $25^{\text {th }}-27^{\text {th }}$ (2004), pp, 232-247. 
Gorman, R. and Adley, C.C. (2004): Characterization of Salmonella enterica serotype Typhimurium isolates from human, food and animal sources in the republic of Ireland. J. Clin.Microbiol., 42(5): 23142316.

Gupta, A.; Fontana, J.; Crowe, C.; Bolstorff, B.; Stout, A.; Van Duyne, S.; Hoekstra, M.P.; Whichard, J.M.; Barrett, T.J. and Angulo, F.J. (2003): Emergence of multidrug-resistant Salmonella enterica serotype Newport infections resistant to expanded - spectrum cephalosporins in United States. J. Infect. Dis., 188: 1707-1716.

Hassan, W.M.M.; Oraby, F.A.I. and Hassan, A.M. (2003): Comparative studies ondifferent isolates of avian salmonellae by Sodium Dodocyl Sulphate Polyacrylamide gel electerophoresis (SDS-PAGE). J. Egypt. Vet. Med. Assoc., 63(2): 65-72.

Helms, M.; Vastrup, P.; Gerner-Smidt, P. and Mobak, K. (2002): Excess mortality associated with antimicrobial drug-resistant Salmonella typhimurium. Emerg. Infect. Dis., 8: 490-495.

Hofer, E.; Silra-Filho, S.J.; Maura, E. and Reis, F. (1998): Salmonella serovars isolated from feedstuff and poultry feeds in Brazil. Pesquisa Veterinaria Brasileira, 18(1): 21-27.

Holt, J.G.; Krieg, N.R.; Sneath, P.A.H.; Staley, J.T. and Williams, S.T. (1996): Bergey's manual of determinative bacteriology, $9^{\text {th }}$ ed., Williams and Wilkins, Baltimore, Maryland, USA.

Johnson, J.M.; Rajic, A. and McMullen, L.M. (2005): Antimicrobial resistance of selected Salmonella isolates from food animals and food in Alberta. Can. Vet. J., 46 (2): 141-146.

Joradat, Z.W. and Zawistowski, J. (1998): Antigenically stable 35 KD outer membrane proteins of Salmonella. Food and Agricultural Immunology, 10(3): 259-270.

Kauffman, G. (1974): Kauffman White Scheme. WHO-BD172, h, Rev.1 Acta. Path. Microbiol. Sci. 61: 385.

Kim, C.J. and Nagaraja, K.V. (1991): An agar gel enzyme assay (AGEA) for simple detection of Salmonella enteritidis antibodies in chicken sera. Diag. Microbiol. Infect. Dis., 14: 203-208.

Laemmeli, U.K. (1970): Cleavage of structural protein during the assembly of head of bacteriophage T4. Nature, 224: 680-684.

Le Minor, L.; Veron, M. and Popoff, M.Y. (1982): Proposal of Salmonella nomenclature. Annales de Microbiologie, 133B, 245-254.

Lee, Y.J.; Kim, K.S. and Kwon, Y.K. (2003): Biochemical characteristics and antimicrobial susceptibility of Salmonella gallinarum isolated in Korea. J. Vet. Sci., 4 (2): 161-166. 
Mallinson, E.T. and Snoeyenbos , G. H. (1989): Salmonellosis: Cited in: A laboratory manual for the isolation and identification of avian pathogens . pp. 3 - 11, 3 rd. Ed., by Purchase, H.G.; Chairman, L.H.Arp; Domermuth, C.H. and Pearson, J.E.. Copies from: American Association of Avian Pathologists.

Murugkar, H.V.; Rahman, H.; Ashkor Komar and Bhattacharyya, D. (2005): Isolation, phage typing and antibiogram of Salmonella from man and animals in northern India. Indian J. Med. Res., (122): 237-242.

Nasef, S.A.A. (1995): Refinement of common antigen for detection of fowl paratyphoid carriers. Ph. D. Thesis (Poultry Diseases), Fac. Vet. Med., Cairo Univ.

National Committee for Clinical Laboratory Standerds (NCCLS) (2003): Performance standards for antimicrobial disk and dilution susceptibility tests for bacteria isolated from animals. Approved StandardM31-A2. Villanova, PA, USA.

Nese, A.; Osmen, S.; Ali, K. and Kurtulus, T. (2003): Immunogenecity and specificity of Salmonella typhimurium outer membrane antigens. J. Cell and Molecular Biology, 2: 91-97.

Novac, S. and Polaharova, A. (1993): Occurrence of Salmonella enteritidis in poultry in various districts of Slovakia in 1990-1992. Veterinarsivi, 43(5): 193-194.

Ochea-Reparaz, J.; Sesma, B.; Alvarez, M.; Jesus, M.; Juan, M. and Gamazo, C. (2004): Humoral immune response in hens naturally infected with Salmonella enteritidis against outer membrane proteins and other surface structural antigens. Vet. Res., 35: 291-298.

Poppe, C. (2000): Salmonella infections in the domestic fowl. In: Salmonella in domestic animals. Ed. By Wray, C. and Wray, A. CABI publishing, CAB international, Wallingford, UK.. pp. 107-132

Qadri, F.; Hossain, S.A.; Giznar, I.; Haidar, K. ; Ljungh, A.; Wadstrom, T. and Sock, D.A. (1988): Congo red binding and salt aggregation as indicators of virulence of Shigella species . J. Clin. Microbiol., 26: 1343-1348.

Roushdy, S.M. (1998): Salmonella outer membrane proteins - immunogenic properties in mice. Ph.D. thesis, Fac., Vet., Med., Cairo Univ.

Sarasombath, S.; Lertmemongkolchai, G. and Banchiun, N. (1988): Characterization of monoclonal antibodies to protein antigen of Salmonella typhi. J. Clin. Microbiol., 26(3): 508- 512.

Shahata, M.A. (1995): Some studies on paratyphoid infections in poultry in upper Egypt. Ph.D. thesis (Poultry Diseases), Fac. Vet. Med., Assiut Univ. 
Talbot, P.J.; Knobler, R.L. and Buchmeier, M.J. (1984): Western and dot immunoblotting analysis of viral antigens and antibodies: application of murine hepatitis virus. J. Immunol. Methods, 73: 177188.

Timoney, J.F.; Sikora, N.; Shivaprasad, H.L. and Opitz, M. (1990): Detection of antibody to Salmonella enteritidis by gm flagellin-based ELISA. Vet. Rec., 127:168-169.

Van Zijderveld, F.G.; Van Zijderveld, Van Bemmel, A.M. and Ankotta, J. (1992): Comparison of four different enzyme - linked immunosorbant assays for serological diagnosis of Salmonella enteritidis infections in experimentally infected chickens. J. Clin. Microbiol., 30: 2560-2566. 